\title{
The effect of the dopamine agonist, apomorphine, on regional cerebral blood flow in normal volunteers
}

\author{
P. M. GRASBY, ${ }^{1}$ K. J. FRISTON, C. J. BENCH, P. J. COWEN, C. D. FRITH, P. F. LIDDLE, \\ R.S.J.FRACKOWIAK AND R. J. DOLAN \\ From the MRC Cyclotron Unit, Hammersmith Hospital; Academic Department of Psychiatry, Royal Free \\ Hospital and School of Medicine; National Hospital for Neurology and Newrosurgery; Department of \\ Psychology, University College, London; and MRC Clinical Pharmacology Unit, Littlemore Hospital, Oxford
}

SYNOPSIS Apomorphine, a non-selective dopamine agonist, has been used as a pharmacological probe for investigating central dopaminergic neurotransmission in psychiatric illness. In this study repeated measurements of regional cerebral blood flow $(\mathrm{rCBF})$ were made in normal volunteers before, and after, the administration of apomorphine $(5$ or $10 \mu \mathrm{g} / \mathrm{kg}$ ), or placebo. The difference in rCBF, before and after drug (apomorphine versus placebo), was used to identify brain areas affected by apomorphine. Compared to placebo, both doses of apomorphine increased blood flow in the anterior cingulate cortex. Apomorphine $10 \mu \mathrm{g} / \mathrm{kg}$ also increased prefrontal $\mathrm{rCBF}$ (right $>$ left). No decreases in $\mathrm{rCBF}$ were noted following either dose of apomorphine. Apomorphine-induced increases of anterior cingulate blood flow might serve as an in vivo index of central dopamine function. Such an approach would complement established neuroendocrine challenge paradigms for investigating central dopamine neurotransmission in psychiatric illness.

\section{INTRODUCTION}

Apomorphine is a non-selective dopamine agonist with central and peripheral actions (Anden et al. 1967; Corsini et al. 1981; Creese, 1987). It has been extensively used as a pharmacological probe of dopaminergic systems in both normal volunteers and psychiatric patients (Checkley, 1980; Meltzer et al. 1984). In neuroendocrine challenge paradigms apomorphineinduced increases in plasma growth hormone are used as an index of central dopamine receptor function (Checkley, 1980; Lal, 1987). Recently, an enhanced growth hormone response to apomorphine has been reported to be predictive of women at high risk of affective psychosis after childbirth (Wieck et al. 1991).

Despite considerable experimental data on apomorphine's central effects in animals, little is known about the brain areas targeted, functionally, by apomorphine in humans. The use of positron emission tomography (PET) to measure drug-induced changes in regional cerebral blood

1 Address for correspondence: D. P. M. Grasby. MRC Cyclotron Unit. Hammersmith Hospital, Du Cane Road, London W12 OHS. flow (rCBF) is potentially a powerful approach to determine brain systems affected by centrally active drugs. Regional cerebral blood flow measurement is, under most circumstances, a valid index of neuronal activity in vivo and, in addition, is sensitive to physiological/ behavioural challenges (McCulloch, 1982; Raichle, 1987; Posner et al. 1988).

Using positron emission tomography (PET) we report the effects on $\mathrm{rCBF}$ of single subcutaneous doses of apomorphine $(5$ and $10 \mu \mathrm{g} / \mathrm{kg}$ ) in normal volunteers. Our aims were to determine: (1) the brain areas altered by apomorphine administration, as indexed by changes in $\mathrm{rCBF}$; and (2) whether the pattern of $\mathrm{rCBF}$ change was consistent with the known distribution of central ascending dopaminergic projections and receptors.

\section{METHOD}

\section{Subjects}

Eighteen right-handed male volunteers (age range 25-36 years) took part in the study which was approved by the Hammersmith Hospital Ethics Committee and the Advisory Committee 
on the Administration of Radioactive Substances (ARSAC) UK.

\section{Drug administration}

Each subject underwent six PET measurements of rCBF over an $80 \mathrm{~min}$ period. Two measurements of $\mathrm{rCBF}$ were undertaken before $(t=-12,-2 \mathrm{~min})$, and four measurements after $(t=+15 .+25,+45$ and $+55 \mathrm{~min})$ subcutaneous apomorphine $5,10 \mu \mathrm{g} / \mathrm{kg}$ or placebo (water for injections). Scan times post apomorphine were chosen on the basis of apomorphine kinetics and the induction of centrally mediated neuroendocrine responses. Time to peak plasma concentration following subcutaneous apomorphine is approximately $8 \mathrm{~min}$ with an estimated elimination half-life of approximately $34 \mathrm{~min}$ (Gancher et al. 1989). Increases of plasma growth hormone begin approximately $15 \mathrm{~min}$ following apomorphine $5 \mu \mathrm{g} / \mathrm{kg}$ injection subcutaneously and reach a maximum at approximately $60 \mathrm{~min}$ (Costain et al. 1982). Subjects were blind to the drug administered. Twelve subjects received apomorphine, six subjects received placebo.

\section{Experimental design}

Subjects performed memory tasks during PET scanning. Such standardization of behavioural state may allow for a reduction in intra- and inter-subject variability in $\mathrm{rCBF}$ (Duara et al. 1987). The behavioural state used for this study was a subspan memory task performed during the 1st, 3rd and 5th scan. A memory task was chosen as the reported experiment formed part of a larger study investigating interactions between monoaminergic drugs and memory processes (Friston et al. 1992). Subjects were asked to remember and immediately recall a series of five-word lists presented auditorily. Nine five-word lists were presented over the two minutes of the PET acquisition scan. Words were presented at the rate of one word every two seconds. Words were high frequency, concrete, imageable and were taken from the Oxford Psycholinguistic Data Base (Quinlan, 1992). In this paper the effect of apomorphine on $\mathrm{rCBF}$ under the subspan task alone is reported. A more complex memory task was performed during the 2 nd, 4 th and 6 th scans; the effects of this task and apomorphine-memory task interactions on $\mathrm{rCBF}$ will be reported separately (see
Friston et al. 1992 for a preliminary report). Apomorphine or placebo was given after the 2nd scan. Subjects' eyes were closed throughout scanning.

\section{PET scanning}

Scans were obtained using a CTI model 93108/12 PET scanner (CTI, Knoxville, TN, USA) (Spinks et al. 1988). Scans were reconstructed using a Hanning filter with a cut-off frequency of 0.5 giving a transaxial resolution of $8.5 \mathrm{~mm}$ full width at half maximum and an axial resolution of $6.75 \mathrm{~mm}$ for each of 15 transverse planes with a resulting total field of view of $10.13 \mathrm{~cm}$ in this direction. To index $\mathrm{rCBF}$, subjects inhaled trace amounts of $\mathrm{C}^{15} \mathrm{O}_{2}$, mixed with air, at a concentration of $6 \mathrm{MBq} / \mathrm{ml}$ and a flow rate of $500 \mathrm{ml} / \mathrm{min}$ through a disposable oxygen face mask for a period of $2 \mathrm{~min}$. Two PET scans were collected over a period of 2.5 min beginning $0.5 \mathrm{~min}$ before the inhalation of $\mathrm{C}^{15} \mathrm{O}_{2}$ (background scan duration $0.5 \mathrm{~min}$, second scan duration $2.0 \mathrm{~min}$ ) (adapted from Lammertsma et al. 1990). In this study, the integrated counts per pixel for the 2 minute build-up phase of radioactivity in the brain during $\mathrm{C}^{15} \mathrm{O}_{2}$ inhalation were used as an index of rCBF (Fox \& Mintun, 1989).

\section{Measurement of plasma growth hormone}

Apomorphine-induced increases in plasma growth hormone were determined from samples obtained from blood drawn from an in-dwelling venous cannula $(t=-20,0,30$ and $60 \mathrm{~min}$ post-apomorphine/placebo). Plasma growth hormone was measured by radioimmunoassay as previously described (Cowen et al. 1985).

\section{Measurement of side effects of apomorphine administration}

Stress and arousal were assessed on three occasions $(t=-15 \mathrm{~min}$ pre-apomorphine/ placebo, +30 and $+60 \mathrm{~min}$, post-apomorphine/placebo) on a 24-item questionnaire (Mackay et al. 1978). In addition, subjects rated nausea, light-headedness and drowsiness on visual analogue scales.

\section{Data analysis}

Each reconstructed $\mathrm{rCBF}$ scan consisting of 15 primary transverse planes was interpolated to 43 planes to render the voxels approximately cubic. 


\section{Apomorphine induced increases in $\mathrm{rCBF}$}

\section{Apomorphine 5}

A

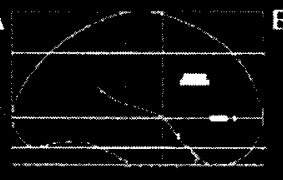

C

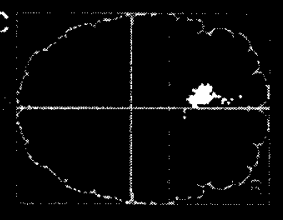

$\mathbf{B}$
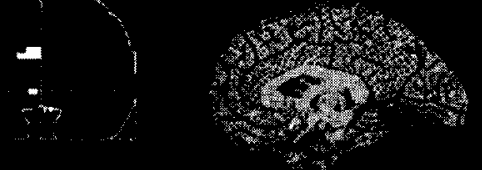

se

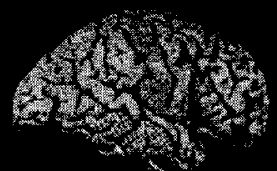

W. cortical rendering

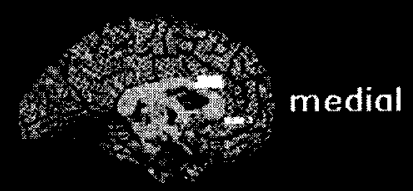

"s:

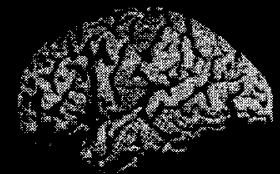

lateral

Apomorphine 10

A

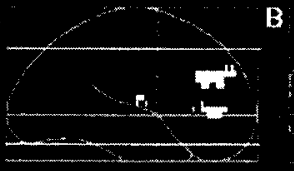

B
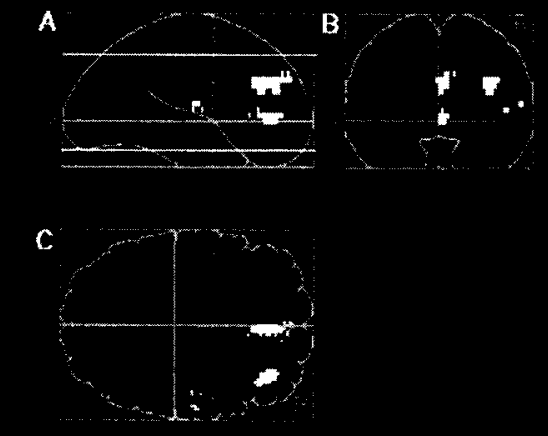
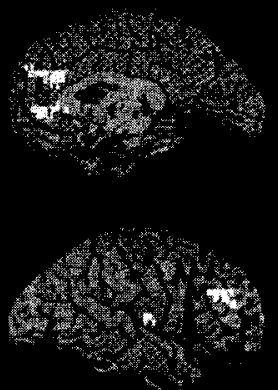

right

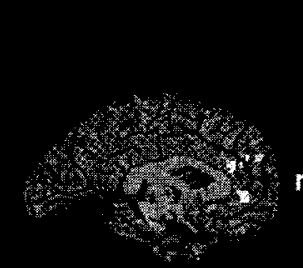

medial

FIG. 1. Location of increases in rCBF following apomorphine ( 10 and $5 \mu \mathrm{g} / \mathrm{kg})$ compared to placebo.

Upper left images: the spatial distribution of significant voxels at $P<0.001$ for apomorphine $(5 \mu \mathrm{g} / \mathrm{kg})$-induced increases in $\mathrm{rCBF}$, compared to placebo. Images are shown as intergrated projections through sagittal $(A)$, coronal $(B)$ and transverse $(C)$ views of the brain. $\mathrm{R}=$ right. The axial extent of the data set is indicated by thick lines in the sagittal (A) view. Upper right: to aid interpretation of the areas of activation significant voxels are rendered onto medical and lateral views of each hemisphere

Lower left images: the spatial distribution voxels at $P<0.001$ for apomorphine $(10 \mu \mathrm{g} / \mathrm{kg})$-induced increases in rCBF compared to placebo. Images are shown as integrated projections through sagittal (A), coronal (B) and transverse (C) views of the brain. $\mathrm{R}=$ right. The axial extent of the data set is indicated by thick lines in the sagittal (A) view. Lower right: to aid interpretation of the areas of activation significant voxels are rendered onto medical and lateral views of each hemisphere. 
The data were then transformed into a standard stereotactic space (Friston et al. 1989, 199la). Such transformation of the data allows for pixel by pixel averaging of data across subjects. In the standard space 1 voxel represents $2 \times 2 \times 4 \mathrm{~mm}$ in the $x, y$ and $z$ dimensions, respectively, allowing direct cross reference to the anatomical features in the standard stereotactic atlas (Talairach \& Tournoux, 1988). A Gaussian filter (20 mm FWHM) was applied to smooth each image to account for inter-subject differences in gyral and functional anatomy and to suppress high frequency noise in the images.

Differences in global activity within and between subjects were removed by analysis of covariance (Wildt \& Ahtola, 1978) on a pixel by pixel basis with global counts as covariate and regional activity across subjects for each task as treatment. This procedure was undertaken as inter- and intra-subject differences in global $\mathrm{CBF}$ may reduce the likelihood of detecting alterations in rCBF following physiological stimulation (Friston et al. 1990). For each pixel, in stereotactic space, the analysis of covariance generated 6 condition-specific (i.e. scans 1-6) mean $\mathrm{rCBF}$ equivalent values (normalized to $50 \mathrm{ml} / \mathrm{dl} / \mathrm{min}$ ) and an associated error variance. This error variance was computed independently for the placebo and apomorphine 5 and $10 \mu \mathrm{g} / \mathrm{kg}$ groups using a completely randomized block design ANCOVA. The changes of interest were rCBF changes attributable to apomorphine that were statistically greater than those induced by placebo. This represents an interaction (predrug $v$. post-drug $\times$ placebo $v$. apomorphine). This interaction term was computed using the $t$ statistic, with the appropriate contrasts (Hand \& Taylor, 1991) and adjusted error variance. The resulting set of $t$ values constitutes a statistical parametric map (SPM(t)) (Friston et al. 1991 b). With so many comparisons being made, many $t$ values will reach conventional levels of significance by chance. Therefore, the 'omnibus' significance of the SPMs was assessed, using the $\chi^{2}$ statistic, by comparing the expected and observed number of $t$ values which exceeded a threshold of $P<0.001$. If this statistic was significant (for a given contrast) the location of all pixels with a $t$ value corresponding to $P<0.001$ was used to define the profile of apomorphine-induced rCBF changes compared to placebo. The results presented are $\mathrm{rCBF}$ data from the first pre-drug scan (scan 1) compared to post-drug scans $(3+5)$, apomorphine 5 or $10 \mu \mathrm{g} / \mathrm{kg}$ compared to placebo. Because of the smoothing filter used (see above) the final individual values for $\mathrm{rCBF}$ at any one pixel represent blood flow in a weighted spherical domain of about $20 \mathrm{~mm}$ diameter.

Image analysis was performed using SPM software (MRC Cyclotron Unit, London, UK) on a SPARC 1 workstation (Sun Microsystems Inc., Surrey, UK) using an interactive image analysis software package (ANALYZE), Biodynamic Research Unit, Mayo Clinic, USA). Calculations and image matrix manipulations were performed in PRO MATLAB (Mathworks Inc., New York).

\section{RESULTS}

Apomorphine-induced changes in $\mathrm{rCBF}$ represent relative increases or decreases compared to placebo. It should be noted that increases and decreases of rCBF may also have occurred outside the axial field of view of the scanner (see Fig. 1).

Observed and expected distribution of $t$ statistic for post-drug (scans $3+5$ ) versus pre-drug (scan 1) comparisons

Significant differences in the observed and expected distribution of the $t$ statistic (at the threshold of $P<0.001)$ for apomorphine $(10 \mu \mathrm{g} / \mathrm{kg})$-induced increases in rCBF compared to placebo were observed $\left(\chi^{2} 40 \cdot 1\right.$, df $1, P<$ $0 \cdot 001)$. Using the $\chi^{2}$ test there was no significance for apomorphine $(10 \mu \mathrm{g} / \mathrm{kg})$-induced decreases $\left(\chi^{2}=0\right.$, df 1$)$. Apomorphine $(5 \mu \mathrm{g} / \mathrm{kg})$-induced increases failed to reach significance at the threshold of $P<0.001$ but were significant at $P<0.01 \quad\left(X^{2}=7 \cdot 10, \quad\right.$ df 1$) . \quad$ Apomorphine $(5 \mu \mathrm{g} / \mathrm{kg})$-induced decreases were not significant $\left(\chi^{2}=0\right.$, df 1$)$.

\section{Sites of apomorphine-induced increases of regional cerebral blood flow}

Two foci of increased regional cerebral blood flow were observed in the anterior cingulate cortex $(2,40,4 \mathrm{~mm}$, and $2,34,24 \mathrm{~mm}$ in Talairach and Tournoux coordinates in the $x, y$ and $z$ plane respectively) following apomorphine $10 \mu \mathrm{g} / \mathrm{kg}$ (Table 1, Fig. 1, Fig. 2). Increased 
Table 1. Coordinates of maximal significant increase in $r C B F$ following apomorphine $10 \mu \mathrm{g} / \mathrm{kg}$ compared to placebo

\begin{tabular}{|c|c|c|c|c|c|}
\hline \multirow[b]{2}{*}{$\begin{array}{l}\text { Anterior cingulate } \\
\text { Scan 3-1 } \\
\text { Scan 5-1 }\end{array}$} & \multicolumn{3}{|c|}{$\begin{array}{l}\text { Coordinates } \\
(x, y, z)\end{array}$} & \multirow{2}{*}{$\begin{array}{l}\text { Apomorphinc } \\
\text { rCBF change } \\
2.73 \pm 1.86 \\
1.97 \pm 1.39\end{array}$} & \multirow{2}{*}{$\begin{array}{c}\begin{array}{c}\text { Placebo } \\
\text { rCBF change }\end{array} \\
-0.74 \pm 1.28 \\
-0.38 \pm 1.72\end{array}$} \\
\hline & 2 & 40 & 4 & & \\
\hline $\begin{array}{l}\text { Anterior cingulitte } \\
\text { Scan 3 1 } \\
\text { Scan 5-1 }\end{array}$ & 2 & 34 & 24 & $\begin{array}{l}2.63 \pm 2.02 \\
1.91 \pm 1.74\end{array}$ & $\begin{array}{l}-1.03 \pm 0.80 \\
-0.88 \pm 0.87\end{array}$ \\
\hline $\begin{array}{l}\text { Right prefromlal } \\
\text { Scan } 3-1 \\
\text { Scan } 51\end{array}$ & 34 & 36 & 28 & $\begin{array}{l}1.95 \pm 0.85 \\
1.83 \pm 1.24\end{array}$ & $\begin{array}{l}-0.79 \pm 1.12 \\
-1.64 \pm 1.04\end{array}$ \\
\hline
\end{tabular}

Stereotatic coordinates of maximal increalses in $\mathrm{C} C \mathrm{BF}$ following apomorphine $10 / \mathrm{gg} / \mathrm{kg}$ and placebo. Coordinates are given in $x, y$, and = coordinites in $\mathrm{mm}$, from the atlas of Talitiach \& Tournoux (1988). Values refer to change in rCBF equivalents (post-drug-predrug) from spherical regions of diameter $20 \mathrm{~mm}$ centred at the coordinates shown. Results in $\mathrm{rCBF}$ equivalents, $\mathrm{ml} / \mathrm{dl} / \mathrm{min}$. mean \pm S.D.

$\mathrm{rCBF}$ was also seen in the right prefrontal cortex following apomorphine $(10 \mu \mathrm{g} / \mathrm{kg})$.

For apomorphine $(5 \mu \mathrm{g} / \mathrm{kg})$ a similar pattern of anterior cingulate increases in $\mathrm{rCBF}$ was noted $(-4,42,0 \mathrm{~mm}$ and $-8,22,24 \mathrm{~mm}$ in Talairach and Tournoux coordinates in the $x, y$ and $z$ plane respectively) (see Fig. 1) although the $\gamma^{2}$ test for this comparison failed to achieve significance at the threshold of $P<0.001$.

\section{Plasma growth hormone following apomorphine} (5 and $10 \mu \mathrm{g} / \mathrm{kg}$ )

Compared to placebo, plasma growth hormone increased following apomorphine administration at 5 and $10 \mu \mathrm{g} / \mathrm{kg}$. This increase was statistically significant for the $10 \mu \mathrm{g} / \mathrm{kg}$ dose (growth hormone; post-drug at $60 \mathrm{~min}$-- predrug; apomorphine $10 \mu \mathrm{g} / \mathrm{kg} 69 \pm 29 * \mathrm{mlU} / \mathrm{l}$, apomorphine $5 \mu \mathrm{g} / \mathrm{kg} 24 \pm 32 \mathrm{mlU} / \mathrm{l}$ and placebo $2 \pm 3 \mathrm{mlU} / 1,{ }^{*} P<0.01$ Student's $t$ test unpaired).

\section{Memory performance, stress, arousal and side effects of apomorphine administration}

Memory performance in the five-word-list memory task was assessed as the total percentage of words correctly recalled during each scan. Both doses of apomorphine had no effect on the percentage of words correctly recalled (apomorphine $10 \mu \mathrm{g} / \mathrm{kg}=98 \cdot 5,98 \cdot 7,98 \cdot 0 \%$ and apomorphine $5 \mu \mathrm{g} / \mathrm{kg}=98 \cdot 0,98.0$ and $100 \%$, means for scans 1,3 and 5 respectively). Measures of stress decreased during the time of the PET study in both apomorphine $5 / \mathrm{g} / \mathrm{kg}$, $10 \mu \mathrm{g} / \mathrm{kg}$ and placebo treated groups. However, arousal increased in the apomorphine $10 \mu \mathrm{g} / \mathrm{kg}$ group (apomorphine $10 \mu \mathrm{g} / \mathrm{kg}$; stress $16 \pm 5$ to $12 \pm 2$, arousal $-3 \pm 4$ to $4 \pm 9$, apomorphine $5 \mu \mathrm{g} / \mathrm{kg}$; stress $17 \pm 2$ to $13 \pm 1$, arousal $-1 \pm 2$ to $-6 \pm 4$, placebo group; stress $19 \pm 2$ to $14 \pm 2$, arousal $-1 \pm 2$ to $-7 \pm 3$, means \pm S.D.). Transient and mild nausea was noted by 3 subjects following apomorphine $10 \mu \mathrm{g} / \mathrm{kg}$ (data not shown).

\section{DISCUSSION}

A remarkably similar profile of apomorphineinduced increases of $\mathrm{rCBF}$ in the anterior cingulate was observed in both the apomorphine $5 \mu \mathrm{g} / \mathrm{kg}$ and $10 \mu \mathrm{g} / \mathrm{kg}$ treated groups (Fig. 1). The foci of these anterior cingulate activations differed by a maximum of 10,12 and $4 \mathrm{~mm}$ only in the $x, y$ and $z$ planes for the two doses of apomorphine and therefore are unlikely to reflect real differences in the sites of activation between doses. In keeping with the drug's rapid onset and short duration of action (Gancher et al. 1989) these increases were greater at the first post-apomorphine $10 \mu \mathrm{g} / \mathrm{kg} \operatorname{scan}(t=15 \mathrm{~min})$ than the second $(t=+45 \mathrm{~min}$ ) (see Table 1 and Fig. 2). Apomorphine-induced increases of $\mathrm{rCBF}$ were also seen in right prefrontal cortex at the $10 \mu \mathrm{g} / \mathrm{kg}$ dose (Fig. 1) and the left prefrontal cortex but only at a lower threshold of $P<0.01$ (data not shown). The similarity in the location of $\mathrm{rCBF}$ increases in the anterior cingulate with both doses of apomorphine is strong evidence for a significant biological effect. It also suggests that non-specific side effects (transient nausea, increased arousal), seen following apomorphine 10 but not $5 \mu \mathrm{g} / \mathrm{kg}$, are unlikely to be a sufficient explanation for the changes in $\mathrm{rCBF}$.

The apomorphine-induced increases of $\mathrm{rCBF}$ in this study are in broad agreement with the reported stimulatory effects of dopamine agonists on cerebral blood flow (CBF) in animals and man. In man, the dopamine agonists apomorphine, piribedil, bromocriptine and the dopamine precursor L-DOPA all increase CBF (Guell et al. 1982; Bes et al. 1983; Leenders et al. 1985; Sabatini et al. 1991). In the anaesthetized baboon apomorphine $(0.02-0.5 \mathrm{mg} / \mathrm{kg})$ also 

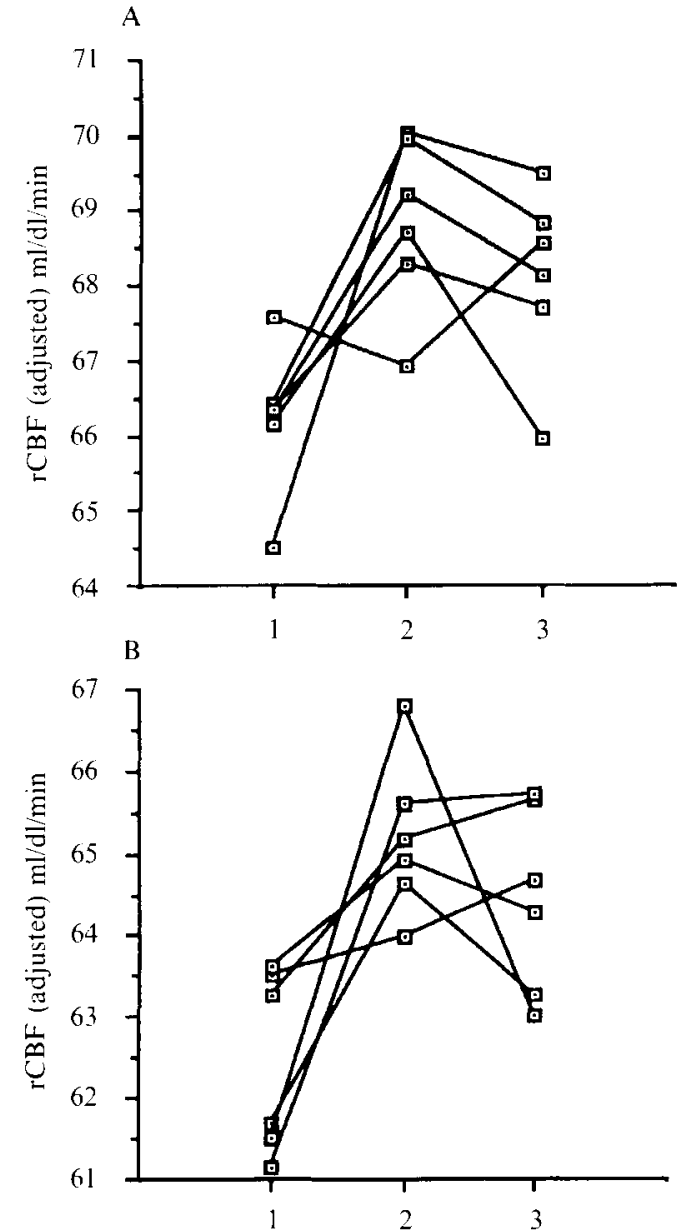

FiG. 2. rCBF increases in the unterior cingulate following apomorphine $(10 / \mathrm{g} / \mathrm{kg})$

Values on ordinate are cerebral blood flow equivalents $(\mathrm{ml} / \mathrm{dl} / \mathrm{min}$ ) for individual subjects, normalized to a global blood flow of $50 \mathrm{ml} / \mathrm{dl} / \mathrm{min}$, in the anterior cingulate at the two foci of maximal change in $\mathrm{CBF}$ (see Table 1 ). A. Anterior cingulate at coordinates 2. 34, $24(\mathrm{~mm}$ in $x, y$ and $z$ planes respectively). B. Anterior cingulate at Talairach and Tournoux coordinates $2,40,4(\mathrm{~mm}$ in $x, 1$ and $z$ planes respectively). $\nabla$. Individual values for $\mathrm{rCBF}$. The abscissa refers to PET scan sequence: 1 , first sean; 2 , third scan; 3 , fifth scan. Apomorphine was given between points 1 and 2 on the abscissa.

increases CBF (McCulloch \& Murray-Harper, 1977). In agreement with our results in some human studies a selective increase in prefrontal rCBF has been noted (Bes et al. 1983; Daniel et al. 1991). In addition, a relative increase in glucose metabolism in frontal areas has been reported by Cleghorn et al. (1991) following apomorphine. In the single tomographic slice examined no anterior cingulate changes were noted (Cleghorn et al. 1991).

Despite agreement on the direction of the expected change in $\mathrm{CBF}$, the mechanism of dopamine agonist induced changes in $\mathrm{CBF}$ is contentious (see McCulloch et al. 1982; Leenders et al. 1985). Either of two mechanisms might account for the observed effects; a direct vasodilatory effect of apomorphine on cerebral blood vessels or an effect of apomorphine on neuronal firing, with consequent changes in glucose metabolism and $\mathrm{rCBF}$. This issue is unresolved at present. For example, in Parkinsonian patients apomorphine $(0.3 \mathrm{mg}$ s.c. $)$ increased global CBF but this effect was blocked by the peripheral dopamine receptor blocker domperidone ( $20 \mathrm{mg}$ t.d.s. for $48 \mathrm{~h}$ ), suggesting a primary vasodilatatory effect of apomorphine 
(Sabatini et al. 1991). In contrast, the increase in $\mathrm{CBF}$ in normal volunteers following the dopamine agonist piribedil was not blocked by domperidone ( $30 \mathrm{mg} 20 \mathrm{~min}$ before piribedil) (Guell et al. 1982) suggesting a direct metabolic effect. Despite the evidence for dopamine receptors in the cerebral vasculature and the vasodilatory effects of dopamine agonists on cerebral vessels in vitro and in vivo (Toda, 1976; Edvinsson et al. 1978, 1985), there is strong evidence from studies in the conscious rat and the anaesthetized baboon that apomorphine induced changes in cerebral blood flow are secondary to changes in cerebral metabolism (McCulloch \& Murray-Harper, 1976; McCulloch et al. 1982). In support of a direct effect of apomorphine on neuronal firing, Cleghorn (1991) has recently reported increased posterior frontal metabolism in normal volunteers following apomorphine $10 \mu \mathrm{g} / \mathrm{kg}$. The discrete regional location of apomorphineinduced increases in $\mathrm{rCBF}$ in this study would also favour an explanation via changes in neuronal activity.

Apomorphine stimulates dopamine autoreceptors located on cell bodies or dendrites of dopaminergic neurones but also acts on dopaminergic receptors post synaptic to dopamine neurones (Aghajanian \& Bunney, 1977). Either or both sites might be the pharmacological site of action of apomorphine at which the effects on $\mathrm{rCBF}$ are mediated. If a direct post-synaptic effect on dopamine receptors in the anterior cingulate is postulated then $D_{1}$ receptor stimulation would seem more likely as dopamine $D_{1}$ receptors are in higher concentration than dopamine $\mathrm{D}_{2}$ receptors in cortical areas (Camps et al. 1989; Cortes et al. 1989). If a direct action on pre-synaptic dopamine autoreceptors is postulated then rCBF changes might be manifest in areas of dense dopaminergic terminal innervation. Unlike the restricted dopaminergic innervation of the rat cortex, in man. most cortical areas are innervated. However, innervation is most dense in the anterior cingulate and motor cortex where dopaminergic projections are to all cortical layers (Berger et al. 1991). Whatever the pharmacological site of action of apomorphine in this study, equivalent studies with dopaminergic agonists in animals would suggest that these effects will best be understood in relation to neuroanatomical circuits
(McCulloch, 1982; Soncrant et al. 1986), of which mesocortical dopaminergic projections are likely to be an important factor.

No striatal activations were noted following either dose of apomorphine. Interestingly, Cleghorn et al. (1991) also reported no changes in striatal activity, indexed by glucose consumption, following apomorphine administration in normal volunteers. Mismatches between drug effects and receptor distributions/terminal innervation patterns are clearly described in the animal functional imaging field (McCulloch, 1982). In addition, putative physiological differences between mesostriatal and mesoneocortical dopaminergic systems (De Keyser et al. 1990) might account for the differential effects of apomorphine in frontal and striatal areas.

Subjects were studied under the condition of five-word-list learning. Memory task induced activations of neuronal circuits may therefore have masked apomorphine effects in certain brain areas. However, any baseline condition, even a 'resting state', is likely to be associated with activations in distributed networks (e.g. attentional systems). Therefore, drug effects will always be manifest in the context of the integrated functioning of activated neuronal systems. As apomorphine did not affect performance in the five-word-list memory task apomorphine's effects are unlikely to represent an alteration in the magnitude or pattern of memory task activation pre-drug versus postdrug.

Further pharmacological characterization with dopamine antagonists is needed to provide a conclusive pharmacological interpretation of our results. Despite this limitation, the results suggest that mapping of central drug effects with PET with serve as an extension to the more established neuroendrocine challenge paradigms for investigating central neurotransmission in psychiatric illness. Thus, while apomorphineinduced increases in plasma growth hormone reflect dopaminergic receptor sensitivity in the hypothalamus (Checkley, 1980), clearly other cortical and limbic structures are more likely candidates for dopaminergic functional abnormalities in psychiatric illness. Apomorphineinduced changes in cingulate $\mathrm{rCBF}$ may provide a direct index of central dopaminergic function in a brain area not currently accessible with neuroendocrine challenges. 


\section{REFERENCES}

Aghajanian, G. K. \& Bunnet, B. S. (1977). Dopamine 'autoreceptors. Pharmacological characterization by micro iontophoretic single cell recording studies. Nammy-Schmiedeberg's Archives of Pharmacology 297, 1-7.

Anden, N.. Rubensen, A.. Fuxe, K. \& Hokfelt, T. (1967). Evidence for dopamine stimulation by apomorphine. Journal of Pharmacy and Pharmacology 19,627-628.

Berger, B.. Gaspar, P.\& Verney, C. (1991). Dopaminergic innervation of the cerebral cortex: unexpected differences between rodents and primates. Trends in the Neurosciences 14, 21--26.

Bes, A Guell, A Fabre N Arne-Bes, M C \& Geraud G (1983) Effects of dopaminergic agonists (piribedil and bromocriptine) on cerebral blood flow in Parkinsonism. Journal of Cerebral Blood Flow and Metabolism 3. suppl \$490-\$491.

Camps, M., Cortes, R., Gueye, B., Probst, A. \& Palacious. J. M (1989). Dopamine receptors in human brain: autoradiographic distribution of D2 sites. Neuroscience $28,275-290$.

Checkley, S. A. (1980) Neuroendocrine tests of monoamine function in man: a review of basic theory and its application to the study of depressive illness. Psychological Medicine 10, 35-53.

Cleghorn, J. M., Szechtman. H. Gamett, E. S., Nahmias, C. Brown. G. M.. Kaplan, R. D., Szechtman, B. \& Franco, S. (1991) Apomorphine effects on brain metabolism in neuroleptic-naive schizophrenic patients. Psychiatry Research Neuroimaging 40. 135-153.

Corsini, G. U., Piccardi, M. P., Bocchetta, F., Bernardi, F. \& Del Zompo. M. (1981). Behavioural effects of apomorphine in man: dopamine receptor implications. In Apomorphine and Othe Dopaminomimetics, Vol. 2: Clinical Pharmacology' (ed. G. U. Corsini and G. L. Gessa), pp. 13-24, Raven Press: New York.

Cortes. R., Gueye, B., Pazos, A., Probst, A. \& Palacious, J. M (1989). Dopamine receptors in human brain: autoradiographic distribution of D1 sites. Neuroscience 28, 263 273.

Costain, D. W., Cowen, P. J., Gelder, M. G. \& Grahamc-Smith, D G. (1982). Electroconvulsive therapy and the brain: evidence for increased dopamine mediated responses. Lancet ii, 400-404

Cowen. P. J., Gadhui. H., Gosden, B. \& Kolakowska, T. (1985) Responses of prolactin and growth hormone 10 L-tryptophan infusion: effects in normal subjects and schizophrenic patients receiving neuroleptics. Psychopharmacology 86, 164-169.

Creese. I. (1987). Biochemical properties of CNS dopamine receptors In Pschopharmacology: The Third Generation of Progress (ed H. Y. Meltzer). pp. 258-260. Raven Press: New York.

Daniel, D. G., Berman, K. F. \& Weinberger, D. R. (1991). The effect of apomorphine on regional cerebral blood flow in schizophrenia Journal of Neuropsychatry 1, 377-384.

De Keyser, J., Herregodts, P. \& Ebinger, G. (1990). The mesoneocortical dopamine neuron system. Neurology 40, 1660-1662.

Duara, R., Gross-Glen, K., Barker, W. W., Chang. J. Y., Apicella A., Lowenstein, D. \& Boothe, T. (1987). Behavioural activation and the variability of cerebral metabolic measurements. Journal of Cerebral Blood Flow and Metabolism 7, 266-271.

Edvinsson, L., Harbedo, J.-E., McCulloch, J. \& Owman, C. (1978) Effects of dopaminergic agonists and antagonists on isolated cerebral blood vessels. Acta Physiologica Scandinavica 105 , 349-359.

Edvinsson, L., McCulloch. J. \& Sharkey, J. (1985). Vasomotor responses of cercbral arterioles in situ to putative dopamine receptor agonists. British Journal of Pharmacology 85, 403-410.

Fox, P. T \& Mintun, M A. (1989). Non-invasive functional brain mapping by change distribution analysis of averaged PET images of $\mathrm{H}_{2}{ }^{15} \mathrm{O}$ tissue activity. Journal of Nuclear Medicine 30, 141-149.

Friston, K. J., Passingham, R. E., Nutt, J. G., Heather, J. D., Sawle, G. V. \& Frackowiak, R. S. J. (1989). Localization in PET images: direct fitting of the intercommissural (AC-PC) line. Journal of Cerebral Blowd Fion and Metabolism 9, 690-695.

Friston. K. J., Frith, C. D., Liddle. P. F., Lammertsma, A. A..
Dolan. R. J. \& Frackowiak, R. S. J. (1990). The relationship between local and global changes in PET scans. Journal of Cerebral Blood Flow and Metabolism 10, 458-466.

Friston, K. J., Frith, C. D., Liddle, P. F. \& Frackowiak, R. S. J. (1991a). Plastic transformation of PET images. Journal of Computer Assisted Tomography 15, 634-639.

Friston, K. J., Frith, C. D., Liddle, P. F. \& Frackowiak, R. S. J. (1991b). Comparing functional (PET) images: the assessment of significant change. Journal of Cerebral Blood Flow and Metabolism 11, 690699 .

Friston, K. J., Grasby, P. M., Bench, C., Frith, C. D., Cowen, P. J., Liddle, P. F., Frackowiak, R. S. J. \& Dolan, R. J. (1992) Measuring the neuromodulatory effects of drugs in man with positron emission tomography. Neuroscience Letters 141, 106-110.

Gancher, S. Woodward W. Boucher, B. \& Nutt, J. (1989). Peripheral pharmacokineties of apomorphine in humans. Ammals of Neurology 26, 232-238

Guell, A. Geraud, G., Jauzac, Ph., Victor, G. \& Arne-Bes, M. C. (1982). Effects of a dopaminergic agonist (piribedil) on cerebral blood flow in man. Journal of Cerebral Blood Flow and Metabolism 2, 255-257.

Hand, D. J. \& Taylor, C. C. (1991). Multivariate Analysis of Variance and Repeated measures pp. 9.44. Chapman and Hall: London.

Lal, S. (1987) Growth hormone response and schizophrenia. In Psuchopharmacology: The Third Generation of Progress (ed. H. Y. Meltzer), pp. 809-818. Raven Press: New York.

Lammertsma, A. A., Cunningham, V. J., Deiber, M. P., Heather, J. D. Bloomfield. P. M. Nutt, J. G., Frackowiak, R. S. J. \& Jones, T. (1990). Combination of dynamic and integral methods for generating reproducible function $\mathrm{CBF}$ images. Journal of Cerebral Blood Flow and Metabolism 10, 675-686.

Leendeers, K. L., Wolfson. L., Gibbs, J. M., Wise, R. J. S., Causon. R., Jones, T. \& Legg, N. J. (1985). The effects of L-dopa on regional cerebral blood flow and oxygen metabolism in patients with Parkinson's disease. Brain 108, 171-191.

Mackay, C. Cox, T., Burrows, G. \& Lazzerini, T. (1978). An inventory for the measurement of self-reported stress and arousal. British Journal of Social and Clinical Psychology 17, 283-284.

MeCulloch, J. (1982). Mapping functional alterations in the CNS with [14C]-deoxyglucose. In Handhook of Pswchopharmacology. (ed. L. I. Iversen, S. D. Iverson and S. H. Snyder), pp. 32l-410. Plenum: New York.

MeCulloch, J. \& Murray-Harper, A. (1977). Cerebral circulation effect of stimulation and blockade of dopamine receptors. American Journal of Physiology 233, $\mathrm{H} 222-\mathrm{H} 227$.

McCulloch, J. Kelly, P. A T \& Ford, I. (1982). Effect of apomorphine on the relationship between local cerebral glucose utilization and local blood flow (with an appendix on its statistical analysis). Journal of Cerebral Blood Flow and Metabolism 2. 487-499.

Meltzer, H. Y. Kolakowska, T., Fang, V. S., Fog., L., Robertson, A., Lewine. R., Strahilevitz. M. \& Busch. D. (1984). Growth hormone and prolactin response to apomorphine in schizophrenia and the major affective disorders. Archives of General Psychiatr. 41, 512-520.

Posner, M. I., Petersen, S. E., Fox, P. T. \& Raichle, M. E. (1988) Localization of cognitive operations in the human brain. Science 240, $1627-1631$.

Quinlan, P. T. (1992). The Oxford Psycholinguistic Database. Oxford University Press: Oxford.

Raichle, M.E. (1987). Circulatory and metabolic correlations of brain function in normal humans. In Handbook of Phisiology. Section 1: The Nervous System. Vol. 5: Higher Functions of the Brain (ed. F. Plum), pp. 643-674. Oxford University Press: New York

Sabatini, U., Rascol, O., Celsis, P.. Houin, G., Rascol, A. \& MarcVergnes. J. P. (1991), Subcutaneous apomorphine increases regional cerebral blood flow in parkinsonian patients via peripheral mechanisms. British Journal of Clinical Pharmacology 32. 229.234 Soncrant, T. T., Pizzolato, G. \& Battistin, L. (1986). The use of drugs as probes of cerebral function In PET and NMR: New Perspectives

PSM 23 
in Neuroimaging and in Clinical Neurochemistry (ed. L. Battistin and F. Gerstenbrand), pp. 131-149. Alan R. Liss: New York. Spinks, T. J.. Jones. T., Gilardi. M. C. \& Heather, J. D. (1988). Physical performance of the latest generation of commercial positron scanner. IEEE Transactions on Nuclear Science 35 $721-725$

Talairach. J. \& Tournoux, P. (1988). A Co-Planar Stereotactic Atlas of the Human Brain. Thieme Verlag: Stuttgart.

Toda, $N$ (1976). Influence of dopamine and noradrenaline on isolated cerebral arteries of the dog. British Journal of Pharmacology 58, 121-126

Wieck, A. Kumar. R., Hirst, A D. Campbell, I. C. \& Checkley, S A (1991). Increased sensitivity of dopamine receptors and S. A. (1991). Increased sensitivity of dopamine psychosis after childbirth. British Medical Journal 303, 613-616.

Wildt, A. R. \& Ahtola, O. T. (1978). Analysis of Covariance. (University papers: quantitative applications in the social sciences Ser. no. 12) Sage Publications: Beverly Hills, CA. 